\title{
Transgrediens et progrediens palmoplantar keratoderma: a case of Greither's disease
}

\section{Postępujący rogowiec dłoni i stóp z transgrediencją - opis przypadku zespołu Greithera}

Przegl Dermatol 2017, 104, 66-67

DOI: https://doi.org//0.5 I |4/dr.2017.66225

Transgrediens et progrediens palmoplantar keratoderma or Greither's disease is a rare type of inherited non-epidermolytic palmoplantar keratoderma characterized by diffuse involvement of palms and soles with an erythematous border that usually presents after 2 years of age and gradually resolves in later life [1]. We present a case of Greither's disease in a male child with classical features but without family history.

A 7-year-old male child was brought to the dermatology outpatient department by his parents with complaints of thickening of the skin of the palms and soles and elevated lesions on the buttocks, knees and elbows for the last 1 month. The lesions began from the center of the palms and soles and had increased in size and thickness during this period. There was no history of excessive sweating of the palms and soles. The boy was born to parents with no history of consanguinity. Antenatal and birth history was uneventful and he showed normal developmental milestones. He had two healthy female siblings. There was no history of similar disease in the family. On examination, diffuse palmoplantar keratoderma

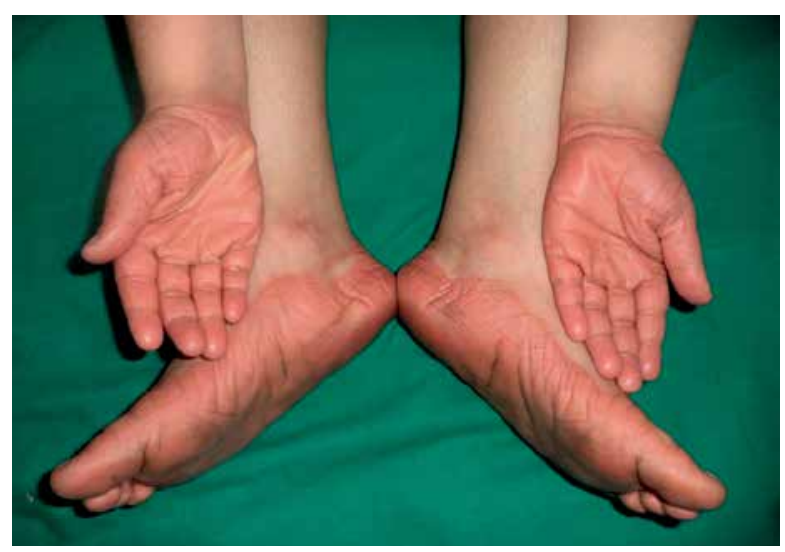

Figure I. Diffuse palmoplantar keratoderma involving both palms and soles

Rycina I. Rozlane ogniska rogowacenia w obrębie dłoni i podeszew with an erythematous border with extension to the dorsum of hands and feet including the digits, ventral wrist and the area overlying the Achilles tendon was present. Erythematous plaques were also seen over the bilateral knees, elbows, lateral malleoli and buttocks. Hair, teeth, nails and mucosae were normal. Systemic examination was unremarkable. Routine investigations were within the normal range. Skin biopsy from the left palm showed orthokeratosis, acanthosis and slight mononuclear infiltrate. Genetic analysis and electron microscopy could not be done due to financial considerations and lack of facilities. Based on the clinical features of the patient and supported by histopathology, a diagnosis of Greither's disease was made.

Transgrediens et progrediens palmoplantar keratoderma was first described in 1952 by Greither by the name of keratosis extremitatum hereditaria progrediens [2]. The disease is transmitted in an autosomal dominant fashion with variable penetrance. It was found in 10 out of 25 members in six generations in a family [3]. Missense mutation in the genes coding for keratin 1 has been described in some

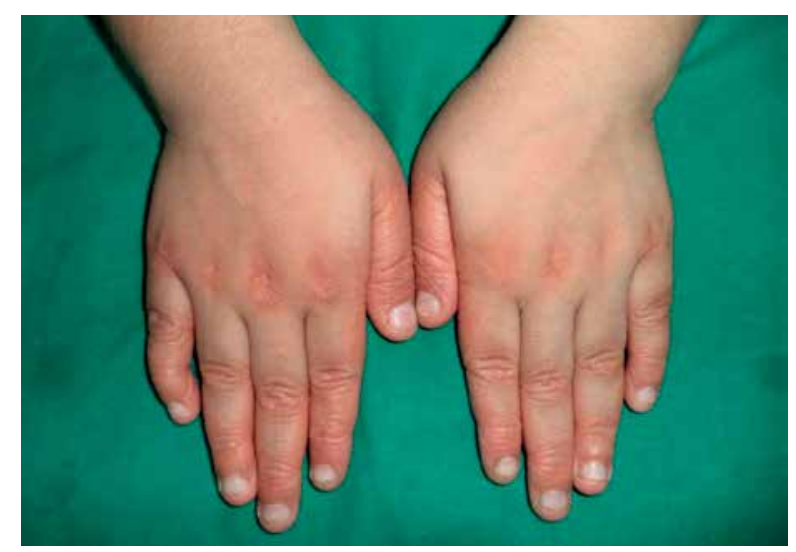

Figure 2. Extension of keratoderma on the dorsal aspect of the hands

Rycina 2. Rozszerzanie się obszaru rogowacenia na powierzchnię grzbietowq rąk 


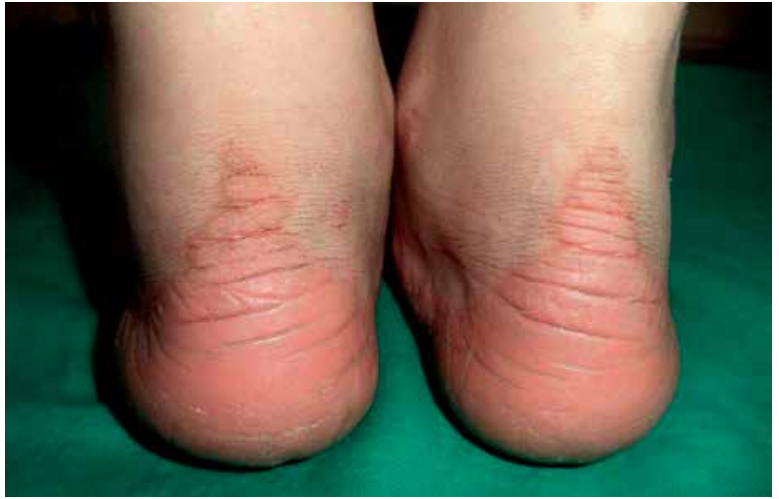

Figure 3. Keratoderma on soles extending proximally to involve the skin overlying the Achilles tendon

Rycina 3. Rogowiec podeszew przechodzący proksymalnie na skórę okolicy ścięgna Achillesa

cases [4]. Clinical features include non-epidermolytic diffuse keratoderma of palms and soles with erythematous border and extension to the dorsal aspect (transgrediens) and the flexural aspect of the wrist (progrediens) and characteristic involvement of the Achilles tendon [5]. Hyperkeratotic plaques are seen on the knees and elbows and sometimes in the flexural areas as well. Hyperhidrosis is usually associated [6]. Lesions begin after the child reaches 2 years, but a few reports of earlier onset have been described [7]. Spontaneous involution of the disease is recognized in the elderly [8]. Histopathology is non-specific and shows orthohyperkeratosis, acanthosis, absence of epidermolysis and perivascular infiltrate consisting mostly of lymphocytes. Electron microscopy shows tonofilament aggregation and an imbricated pattern of desmosomes and cell junctions [9].

Differential diagnosis includes Mal de Meleda palmoplantar keratoderma (PPK), which is differentiated by its autosomal recessive transmission, formation of constrictive bands, ivory white hyperkeratosis and nail changes. Vorner palmoplantar keratoderma is autosomal dominant but begins soon after birth, is non-transgrediens and shows epidermolysis. Greither's disease is considered by some authors to be a variant of Unna-Thost palmoplantar keratoderma [8], but features such as early onset, absence of transgrediens and lack of involution in later life make most authors classify Greither's disease as a separate entity $[3,7,9]$. Treatment of Greither's disease is difficult and includes salt-water soaks, topical keratolytics and systemic steroids [10].

We have reported the case of patient with all classical features of Greither's disease. However, family history suggesting autosomal dominant transmission was not present. This could be due to variable penetration of the disease, as previously reported in the literature [3]. However, features such as late on-

Received: $28 \times 2016$

Accepted: 21 I 2017

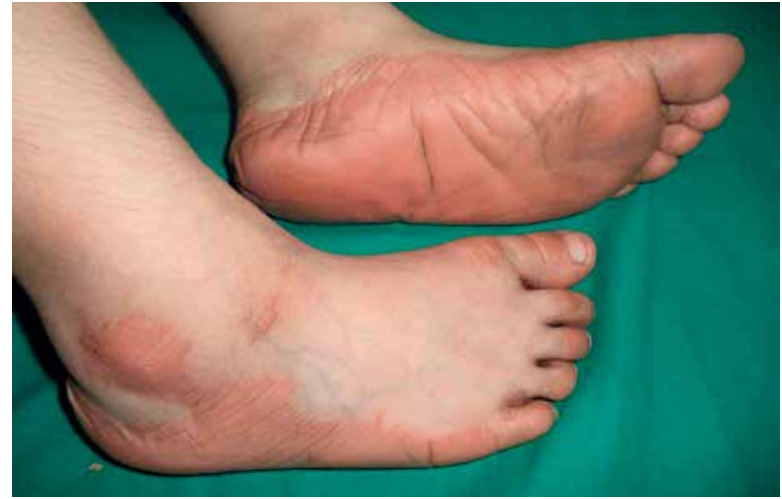

Figure 4. Extension of plantar keratoderma to the lateral malleolus Rycina 4. Szerzenie się rogowca podeszew na okolicę kostki bocznej

set, non-epidermolytic palmoplantar transgrediens and progrediens keratoderma with erythematous border, involvement of skin over the Achilles tendon and compatible histopathology suggest that this was a case of Greither's disease, an uncommon palmoplantar keratoderma rarely reported in the literature.

\section{References}

1. Oji V., Metze D., Traupe H.: Inherited disorders of cornification. [In:]: C.E.M. Griffiths, J. Barker, T. Bleiker, R. Chalmers, D. Creamer (eds.). Rook's Textbook of Dermatology. $9^{\text {th }}$ ed. Wiley Blackwell, London, 2016, 65.46-7.

2. Greither A.: Keratosis extremitatum hereditaria progrediens mit dominantem. Erbgang Hautarzt 1952, 3, 198-203.

3. Grilli R., Aguilar A., Escalonilla P., Soriano L., Fariña C., Martín L., et al.: Transgrediens et progrediens palmoplantar keratoderma (Greither's disease) with particular histopathologic findings. Cutis 2000, 65, 141-145.

4. Gach J.E., Munro C.S., Lane E.B., Wilson N.J., Moss C.: Two families with Greither's syndrome caused by a keratin 1 mutation. J Am Acad Dermatol 2005, 53 Suppl., S225S230.

5. Singh T., Yadav S., Dhillon K.S., Khan N., Khan A., Srivastava S., et al.: Greither's disease: a case report. Int J Adv Med 2015, 2, 291-293.

6. Athanikar S.B., Inamadar A.C., Palit A., Sampagavi V.V., Deshmukh N.S.: Greither's disease. Indian J Dermatol Venereol Leprol 2003, 69, 292-293.

7. Beylot-Barry M., Taieb A., Surleve-Bazeille J.E., Maleville J.: Inflammatory familial palmoplantar keratoderma: Greither's disease? Dermatology 1992, 185, 210-214.

8. Tay Y.K.: What syndrome is this? Greither's syndrome (Transgradiens et progradiens palmoplantar keratoderma). Pediatr Dermatol 2003, 20, 272-275.

9. Fluckiger R., Itin P.H.: Keratosis extremitatum (Greither'sdisease): clinical features, histology, ultrastructure. Dermatology 1993, 187, 309-311.

10. Ratnavel R.C., Griffiths W.A.D.: The inherited palmoplantar keratodermas. Br J Dermatol 1997, 137, 485-490.

Tasleem Arif, Mohammad Adil, Syed Suhail Amin, Konchok Dorjay Jawaharlal Nehru Medical College (JNMC), Aligarh Muslim University (AMU), Aligarh, India 